\title{
Bibliometric analysis of international researches on innovation metrics
}

\author{
Marcos Ferasso* and \\ Ana Paula Mussi Szabo Cherobim
}

Federal University of Parana, R. Lothario Meissner, 632 Curitiba, Parana 80210-170, Brazil

Fax: +55-41-3408-8397

Fax: $+55-413-360-4365$

Email: admmarcos@admmarcos.adm.br

Email: anapaulamussi@ufpr.br

*Corresponding author

\begin{abstract}
This bibliometric study aims to identify the state of art of international bibliography related to innovation metrics theme. This paper discusses several intents in measuring innovation through metrics and models due to the fact that innovation occurs in a more contextual way and formed by multi-faceted indicators that go beyond a rigid measure modelling. Using the period of the last ten years and Boolean searches for key terms in Web of Science databases, we selected 136 papers that were captured by EndNote Web. Results were analysed through two phases: the quantitative results were sorted in descending order and we noticed a publication increase during the studied period. The journals that gather the bigger number of selected publications were research policy and technovation. The second qualitative analysis categorised selected papers after reading all abstracts and we found that the metrics that appeared the most are number of patents, performance, innovations in product and process, inputs and outputs, innovative activities and capabilities, R\&D, and firms' structure and interactions.
\end{abstract}

Keywords: bibliometrics; metrics; innovation.

Reference to this paper should be made as follows: Ferasso, M. and Cherobim, A.P.M.S. (2017) 'Bibliometric analysis of international researches on innovation metrics', Int. J. Bibliometrics in Business and Management, Vol. 1, No. 1, pp.26-51.

Biographical notes: Marcos Ferasso earned his Bachelor's Diploma in Management from University of the West of Santa Catarina (Brazil) in 2002, his Specialisation Diploma in Business Management from University of the West of Santa Catarina (Brazil) in 2005, his Specialisation Diploma in Local Development from International Labor Organization/United Nations (Italy) in 2006, and earned his MSc in Management from Federal University of Rio Grande do Sul (Brazil) in 2009, with an exchange period as a Visiting Professor at Euromed-Marseille Ecole de Management (France). Currently, he is a $\mathrm{PhD}$ Management student at Federal University of Parana. His research interests include knowledge management, clusters, small enterprises, strategy and local/regional development. 


\begin{abstract}
Ana Paula Mussi Szabo Cherobim is the Director of Applied Social Sciences Division at UFPR, Associate Professor II at the Department of General and Applied Administration and Professor of the Graduate program in Management. She has experience in administration, with emphasis in financial management, acting on the following topics: investment in technological innovation, funding for innovation, competitiveness and value creation. She graduated in Economic Sciences (1985) and Business Administration (1992) at the Federal University of Paraná. She is a finance specialist at IAG/PUC (1988), and she received her Master of Technology degree from the Federal Technological University of Paraná (1997) and $\mathrm{PhD}$ in Business Administration from the University of São Paulo (2002).
\end{abstract}

\title{
1 Introduction
}

The measurement of innovation aroused and still wakens scientific curiosity of researchers and we find different proposals from those involved on microeconomic indicators from those involved on macroeconomic indicators. However, innovation is not something linear and predictable; likewise serendipities (Graebner, 2004) and disruptive innovations (Christensen, 1999, 2004; Christensen and Raynor, 2003; Utterback and Acee, 2005) confirm this fact. Innovations measurements strictly based on number of patents can incur errors as well (Crosby, 2000; Sakakibara and Branstetter, 1999; Kleinknecht et al., 2002) because there are industries (such as informatics) where patent loses its commercial value, contrary to what occurs in the pharmaceutical industry, for example, where patent lasts decades and adds to the firm's value.

Among the available metrics, the Oslo Manual (relative to innovation) and the Frascati Manual (relative to $R \& D$ ) are among the most used references to measure country-level innovation (OECD, 2005, 2007). These two manuals represent a conceptual framework based on a trial conceptual and statistics standardisation about technological innovation. Such manuals support the adoption of metrics for measuring innovation whether it is on a microeconomic or macroeconomic level, but with different methodologies (Jalles, 2010; Katila, 2000). In addition, the specificity of industries (Becker and Dietz, 2004; Eisenhardt and Tabrizi, 1995; Stuart, 2000; Lim, 2004; Voss, 1992; Avermaete et al., 2003) turns out to require specific indicators that may not be generalisable to other industries or in other times. As Geisler (2000) stated, there are difficulties in constructing a metric that relies heavily on quantitative-subjective metrics categories and with qualitative and integrated indicators, since the measure always depends on the user's needs and data availability (Werner and Souder, 1997).

Among several concepts and theories, the metrics concept used in this paper is aligned to the definition of Geisler (2000): a description of a measures system that includes items to be measured, unit of measure, and unit value. The same author underlined that when it comes to innovation, science and technology data (S\&T) are extracted from the innovation's history. Innovation is understood, in this paper, from Schumpeter's (1934) concepts, regarding new product and new process by which innovation is achieved. 
Considering that Oslo Manual was created in 1990 (the current edition is from 2005) and Frascati Manual is dated 1963 (the sixth edition in use is from 2002), this paper aimed to identify the state of art of international bibliography related to innovation metrics theme in the last ten years. The period was selected to represent an attempt to obtain the most current results about the possible alternatives for measuring innovation. Thus, we stress the following research problem: what is the state of art of international literature about innovation metrics theme?

As a justification, it is shown that no international bibliometrics were found on the subject and this research aimed to provide a state of art in such a theme, and due to the specification and consolidation of metrics to be used both in the macroeconomic, mesoeconomic or microeconomic levels. As befits bibliometric studies, this research seeks to identify leading publications in literature, and identify the most commonly used metrics and what are their characteristics. It is also expected that results of this research will stimulate further research on the topic.

This paper is divided into four sections. The first presents the theoretical gap, purpose and justification for the study; the second presents the methods used for bibliometric research; the third presents the results and the fourth shows results discussion and concludes the paper with some limitations and guidance for future researches, followed by references.

\section{Research method}

This bibliometric study is characterised by the research of papers and their citations (Narin, 1976; Moed et al., 1985; Borgman and Furner, 2002). Scientific publications were retrieved by the search of key terms in databases. Key search terms were validated by five researchers of the area in study during a research group meeting in November, 2014.

We used social sciences citation index - SSCI, (Moed et al., 1985) as the basis for citations, since the sciences citation index - SCI is an important recovery tool of scientific publications (Narin, 1976). Thus, citations (Borgman and Furner, 2002) were used as an evaluation measure from $\mathrm{H}$ index (Hirsch, 2005, 2007). The SSCI allowed us to quantify scientific contributions and rank the developed researches over the years (according to journal quality, impact factor, citations number). Some attempts to measure the financial success consider a quantification of patents, licences or royalties (Saguy et al., 2013). The period of paper collection occurred from November to December 2014.

As procedures for papers detection, we performed the following searches.

1 Search for research papers by key term in the databases Portal Periodicos CAPES and Web of Knowledge. 
a The first search was done in Brazilian database Portal Periodicos Capes by selecting the databases in the area of Applied Social Sciences sub-area: business management, which comprises 70-bases. There is a restriction on the selection of databases for simultaneous search; then the following databases were selected: Cambridge Journals Online, Emerald Insight, JSTOR Arts \& Sciences III, Oxford Journals, SAGE Journals, Science Direct, Scopus, EBSCO, Web of Science, and Wiley Online Library. These bases were chosen due to the amount of indexed journals and international importance of the databases. As Boolean search for key terms 'innovation' AND 'metric*' (for variances of metric or metrics), and we selected the period of last ten years according to criteria of Bruni (2008) when saying that longer periods improve the confidence level of research; and as last selection criterion we selected only complete journal papers. This search resulted in a total of 85 papers.

For selection of valid papers to proceed to the next phase of research, we revised each paper regarding title, abstract, keywords and journal in which the paper was published (adhering to the area of management and economics, other areas were excluded), with an inclusion criterion to contain both search terms (metric and innovation; innovation and metrics). Papers were ranked in descending order of citations. From 85 articles, only 15 articles were selected for reading all abstract for further selection. These papers were captured by EndNote Web.

b In attempting to find more papers for this bibliometry, the same procedures were used in Web of Science database. At this stage, for the same period, we recovered 436 articles that scored in descending order of citations. Among these, 71 were select for the next stage and these papers were capture by EndNote Web.

Excluding 13 duplicated papers (comparing the CAPES journals and Web of Knowledge databases), we obtained only two papers in CAPES journals and 68 in Web of Science. Since Web of Science database is available via CAPES journals and considering the high score of repeated papers and the higher number of papers in Web of Science, we decided to continue the search only on this database.

2 In order to obtain possible variations of the search term, we performed a second search with Boolean terms 'innovati*' AND 'measur*' (the first appearance of possibilities for the terms 'innovation' or 'innovative activity' or 'innovative activities', the second for the emergence of possibilities of terms like 'measure', 'measures' or 'measuring') in Web of Knowledge. The same procedures used to retrieve papers at the previous stage were kept in this stage. As results, we obtained 14,380 publications. To restrict the journals in the field (as the terms may be present in journals from different fields of knowledge), we decided to restrict to the following research areas: 'business and economics', 'public administration' and 'science technology other topics', owing to the high number of papers considered false positives without restriction area (notably in the areas of health and engineering). With these criteria, we obtained 3,425 publications that were also ranked in descending order of citations, and we performed an examination of title, abstract, keywords and journal in which the article was published, adopting the same 
previous criteria. From 3,425 papers, only 178 papers were selected for reading all abstracts for further selection. These papers were captured by EndNote Web.

3 In a third attempt for searching new key terms that could possibly report results that could contribute to this research, we decided to use the same procedures of two previous phases, with the terms 'innovation index'. Research in Web of Science returned a total of 23 papers, of which four were captured by Endnote Web for further analysis.

Table 3 illustrates the possible terms combinations on the subject, used in Boolean search.

After all the above collections, we gathered 250 papers in one folder to find potential duplications. When none where found, the collection phase was ended.

4 The procedures adopted for paper analysis followed the postulates of Borgman and Furner (2002), with a ranking in descending order of citations. Selected papers which have not received any citation were removed at this stage, as postulated Ho (2007), Radicchi et al. (2008) and Baghele et al. (2014), and 217 papers remained for further analysis. From this classification, all abstracts of selected papers were carefully and rigorously read in order to identify false positives. The procedure allowed the identification of 81 false positives, leaving 136 papers for bibliometrics calculations.

For themes identification and after an analysis of 136 papers, we categorised (Bardin, 1977) as the metrics used as a parameter and this procedure allowed the identification of key metrics adopted in selected publications.

Table 1 Results of papers by indexed databases in CAPES journals database

\begin{tabular}{lc}
\hline Database & Number of retrieved papers \\
\hline Wiley Online Library & 27 \\
JSTOR Arts \& Sciences III & 25 \\
Oxford Journals & 24 \\
Cambridge Journals & 9 \\
\hline
\end{tabular}

Table 2 Results of papers per year of publication in the CAPES journals database

\begin{tabular}{lc}
\hline Publication period & Number of retrieved papers \\
\hline Before 2006 & 3 \\
From 2006 to 2007 & 6 \\
From 2008 to 2009 & 14 \\
From 2010 to 2012 & 34 \\
After 2012 & 28 \\
\hline
\end{tabular}


Table 3 Boolean search combinations of key terms

\begin{tabular}{|c|c|c|c|}
\hline Boolean term & & Variations & \\
\hline \multirow[t]{4}{*}{ innovati* } & & Innovation & \\
\hline & & Innovations & \\
\hline & Innovative & & Activity \\
\hline & & & Activities \\
\hline \multicolumn{4}{|l|}{ AND } \\
\hline \multirow[t]{2}{*}{ metric* } & & Metric & \\
\hline & & Metrics & \\
\hline \multirow[t]{6}{*}{ measur* } & & Measure & \\
\hline & & Measures & \\
\hline & & Measuring & \\
\hline & & Measurement & \\
\hline & & Measurements & \\
\hline & & Measured & \\
\hline Index & & & \\
\hline
\end{tabular}

Source: Constructed with base in Catapan and Cherobim (2010)

In the application of bibliometric research, some limitations emerged: a database restriction to the Web of Science limited to scientific journals indexed in this database. Using EndNote Web was limited to allowing an agile collection which helped in the bibliometric analyses. The collection period was from November to December 2014.

\section{Results presentation}

From reading the abstracts and identifying other information of 136 selected papers that we reached at the end of the collection, it was revealed that there is a great heterogeneity of published researches' authors, and only one paper was published by the same author, according to the criteria of Library Science authorities. We used as a parameter of analysis the highest number of citations (Borgman and Furner, 2002) ranking all selected research papers in descending order.

This section is divided into two sub-sections: the first of quantitative analyses and the second consisting of qualitative analyses of selected publications.

\subsection{Quantitative analysis of selected papers}

Regarding the total citations, the ten most cited papers account for $40.58 \%$ (775) of the total citations $(1,910)$ (Table 4$)$. We chose these the ten most cited papers in accordance with the criteria of Albarrán et al. (2011).

The distribution of citations number and papers total evidenced this heterogeneity. The ratio of total number of published papers per year is illustrated in Figure 1, and we perceived the relative increase of publications in the analysed decade by considering the trend line (dotted line). 
Table 4 The ten most cited papers and the total of citations

\begin{tabular}{lc}
\hline Research paper & Total of citations \\
\hline Lanjouw and Schankeman (2004) & 172 \\
van de Vrande et al., (2009) & 119 \\
Becker and Dietz (2004) & 98 \\
Hu and Mathews (2005) & 64 \\
Sorescu and Spanjol (2008) & 59 \\
Szymanski et al. (2007) & 59 \\
Armbruster et al. (2008) & 54 \\
Mansury and Love (2008) & 51 \\
Yi et al. (2006) & 50 \\
Bilbao-Osorio and Rodriguez-Pose & 49 \\
(2004) & \\
\hline
\end{tabular}

Figure 1 Total distribution of published papers per year (see online version for colours)

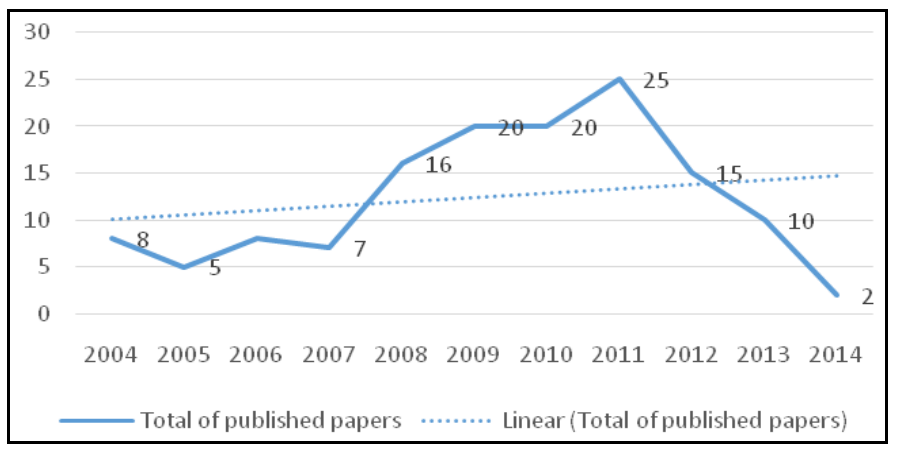

The ten journals that had most publications in the selected period are presented in Table 5.

Table 5 The ten journals with more published papers in the selected period

\begin{tabular}{lcc}
\hline Journals & $\begin{array}{c}\text { Total of published } \\
\text { papers }\end{array}$ & $\begin{array}{c}\text { JCR-ISI impact } \\
\text { factor }\end{array}$ \\
\hline Research Policy & 11 & 2.598 \\
Technovation & 10 & 2.704 \\
Journal of Product Innovation Management & 4 & 1.379 \\
Service Industries Journal & 4 & 2.58 \\
African Journal of Business Management & 3 & $*$ \\
Economic Development Quarterly & 3 & 0.510 \\
Industry and Innovation & 3 & 1.116 \\
Innovation-Management Policy \& Practice & 3 & 0.439 \\
International Journal of Technology Management & 3 & 0.492 \\
Journal of Technology Transfer & 3 & 1.305 \\
\hline
\end{tabular}

Notes: *ISI impact factor unavailable. Not considered in this research for statistics. 
We observed that the main journals are 'Research Policy' and 'Technovation', both with ISI Impact Factor above 2.0; and both in the area of research and technology. Regarding Eigenfactor ${ }^{\circledR}$ metrics, which measures the influence of the journal compared to the others, the journal 'Research Policy' has an index of 0.01573 and 'Technovation' journal has a score of 0.00435 .

\subsection{Qualitative analyses of selected papers}

From reading all abstracts, we identified issues and metrics used in each of 136 selected papers. Using the categorisation technique (Bardin, 1977), we grouped papers considering innovation metrics by identifying indicators or statistical and mathematical models used on those papers. This technique allows the categorisation showed on Table 6.

The contents categorisation of papers evidenced the heterogeneity and multiplicity of innovation metrics used in different industries. It is noteworthy that even in the same sector, or in the same study area, there was no a single metric that can be used to measure innovation according to the specificities of each industry and the criteria adopted by researchers to perform the measure. However, among the 136 analysed publications, some repetitions were evidenced: number of patents, performance measurement, product innovation, process innovation, inputs and outputs, innovative activities, innovative capabilities, R\&D, and firm's structure and interactions (or network).

There is a concentration of researchers who still use traditional innovation metrics by number of patents and those using performance measurements as an indicator of innovative activities. This is explained by the practicality of measuring number of patents that a particular company owns but, when considering industries which technologicalbase occurs in open innovation, patent ownership does not result in competitive advantages due to market evolution speed of this product as well as the very short product life cycle (such as in the software industry), where the product disappears from the market even before obtaining the patent. Metrics based on patents show themselves a valid metric source for technology-based industries where product life cycle is longer than the time required for obtaining the patent as a protective measure of such innovation. As shown by Ferasso (2013), in sectors that are not eligible for patents, the secrets are the usual forms in protecting innovations.

Then the indicators most commonly used as parameter for measuring innovation were the internal products and processes, in addition to inputs and outputs. The consideration of innovation from product and process is aligned with Schumpeter's (1934) concepts, yet the inputs are related to resources that a given firm affords to change them, add value and bring to market a product or innovative service (output). Thus, we perceived that there is coherence in considering processes and products as innovation indicators, however, there is the same difficulty of constructing a formula or model that can be generalised to other industries.

Another aspect that draws attention is related to specific characteristics of firms with respect to their activities and innovative capacities, interactions and their own organisational structure. These indicators can be considered as aggregates to the firm management and, as is known, firms have different performances depending on the manager's decisions and available resources. 
Table 6 Categorisation of constructs, indicators, measurements and levels of analysis of selected papers

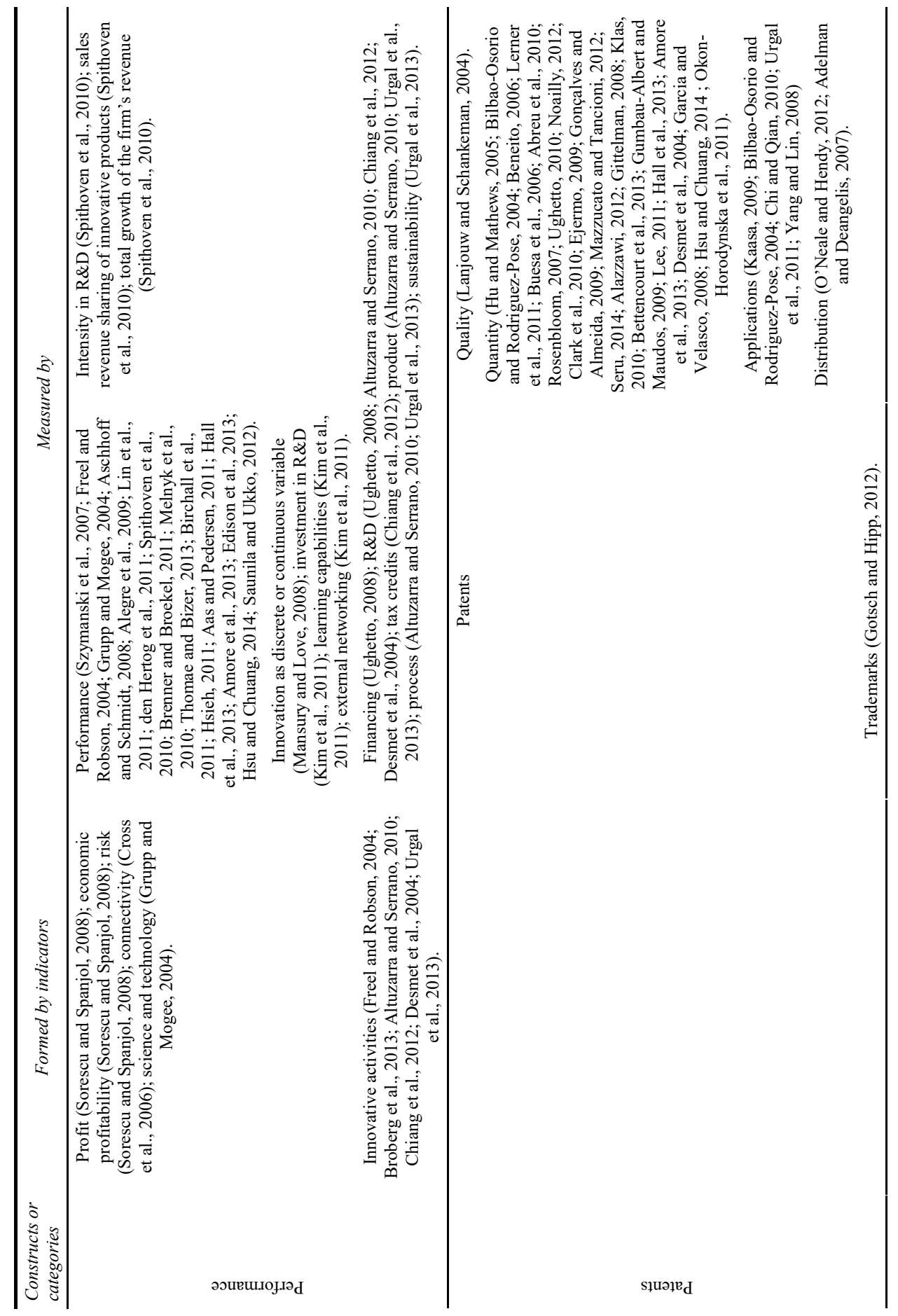


Table 6 Categorisation of constructs, indicators, measurements and levels of analysis of selected papers (continued)

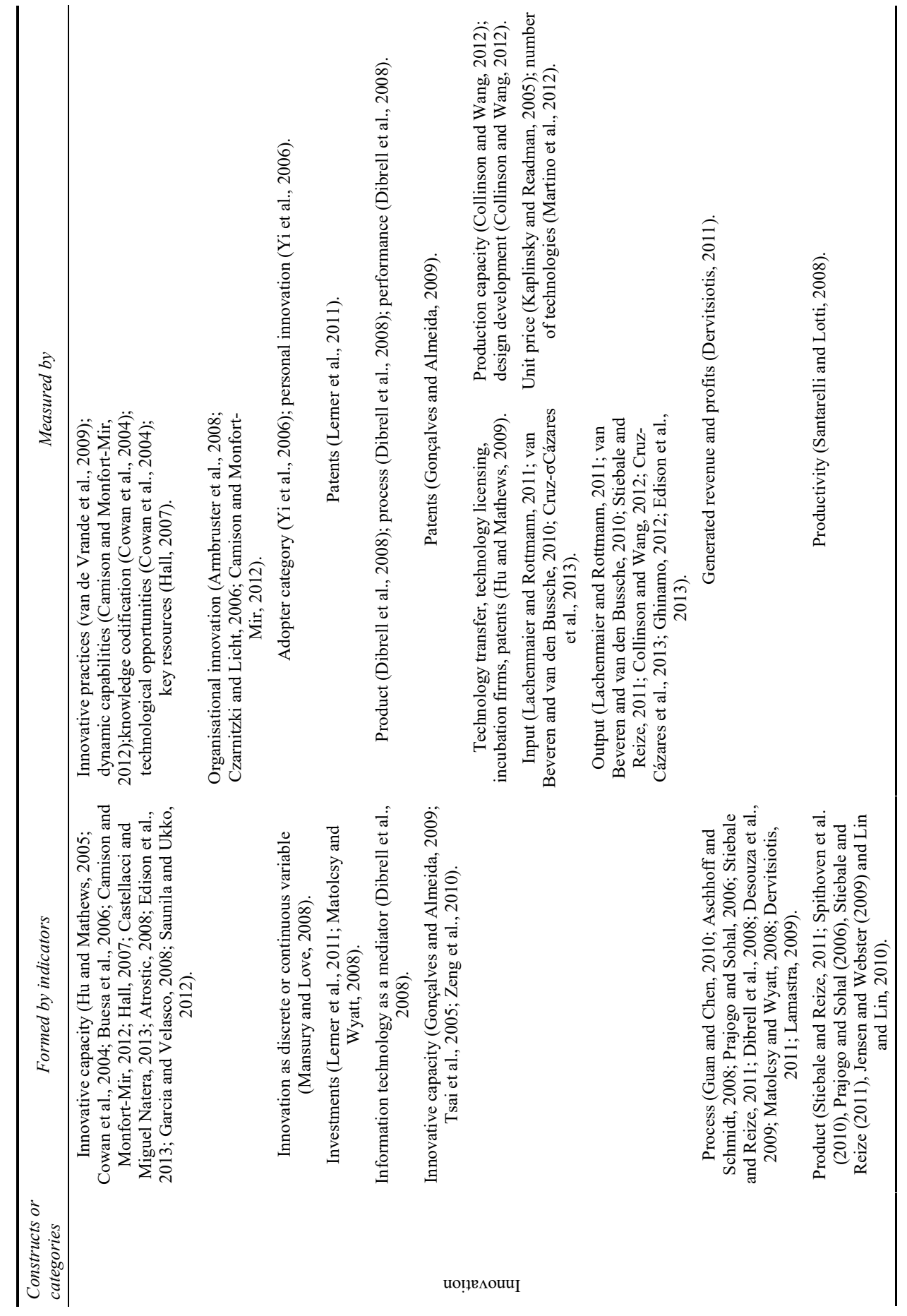


Table 6 Categorisation of constructs, indicators, measurements and levels of analysis of selected papers (continued)

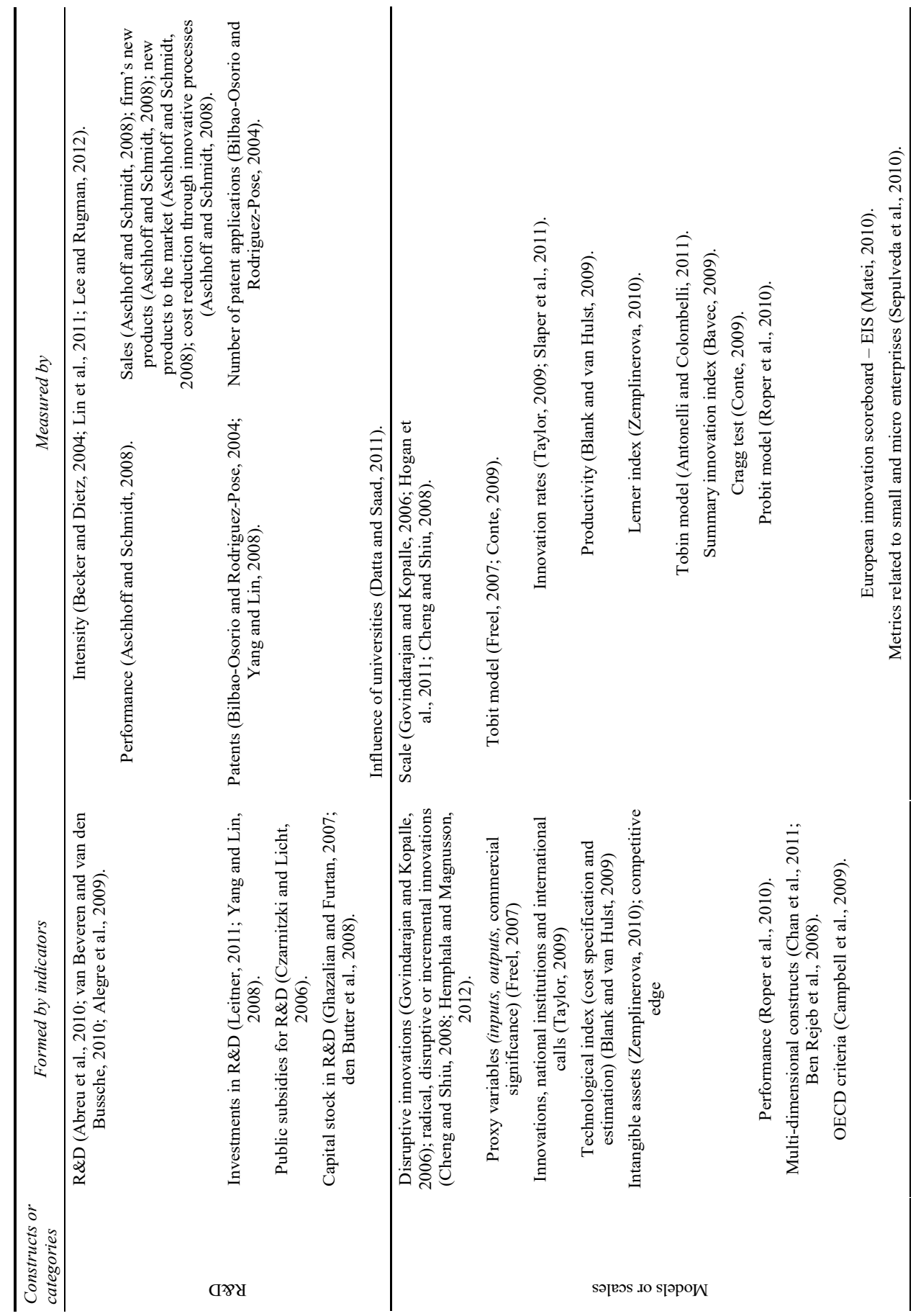


Table 6 Categorisation of constructs, indicators, measurements and levels of analysis of selected papers (continued)

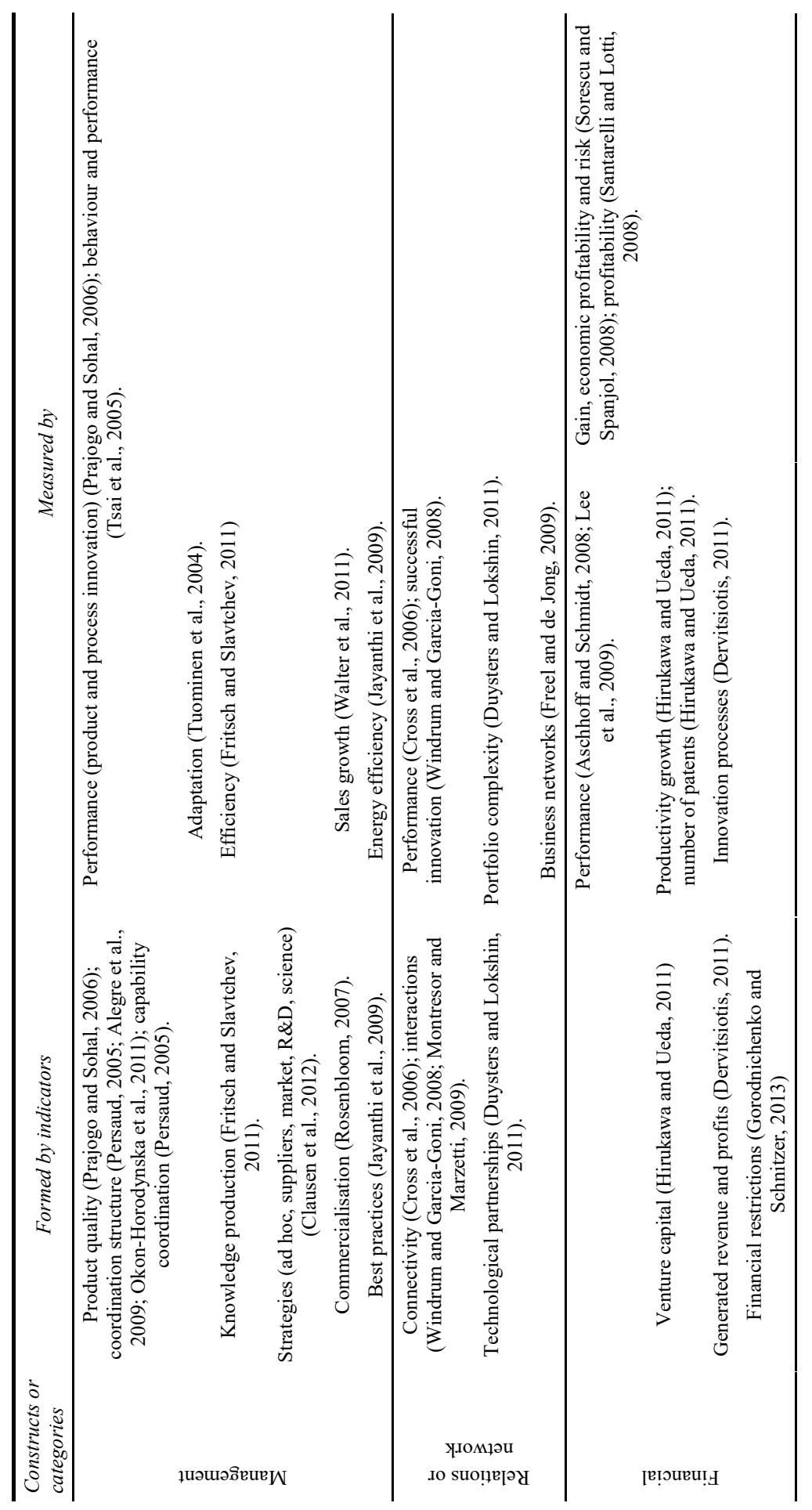


Table 6 Categorisation of constructs, indicators, measurements and levels of analysis of selected papers (continued)

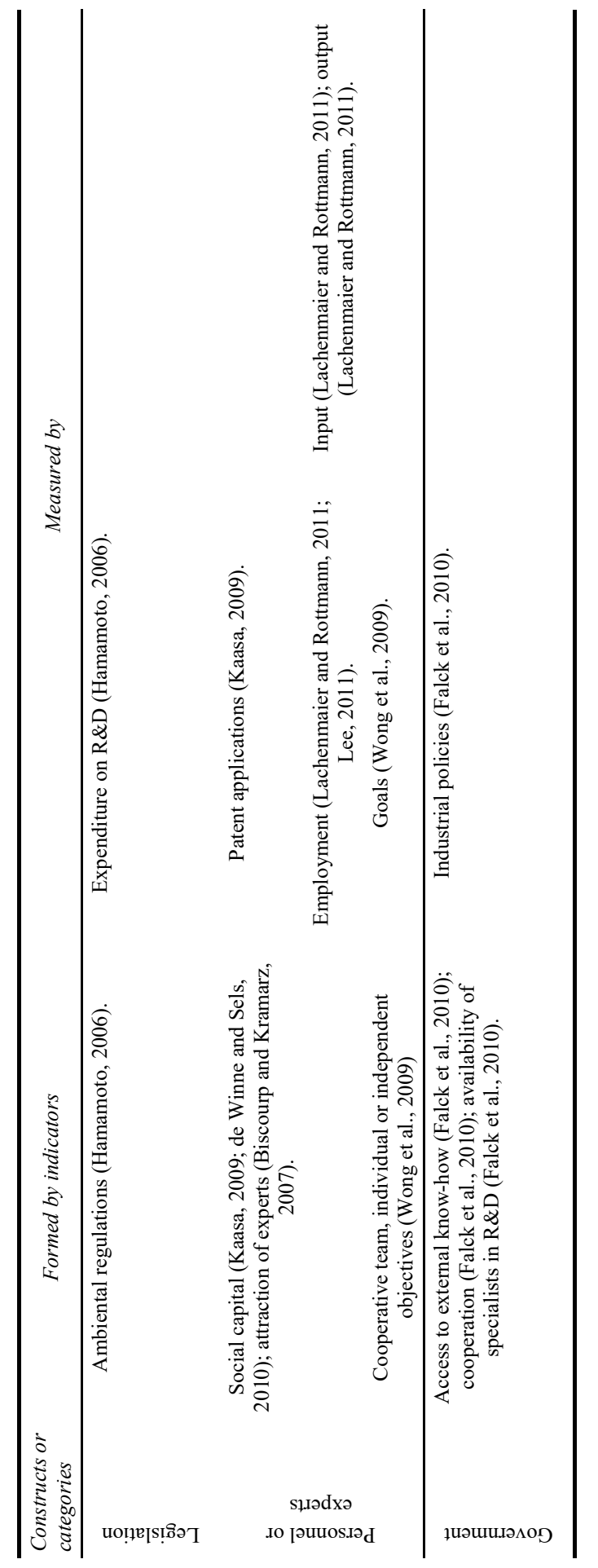


We found a contrast between the constant interest of researchers in bind investments and $R \& D$ innovation. There is a recurrent association of $R \& D$ and innovation performance, largely because technology-based industries need investments in $R \& D$ to develop innovative processes and products.

Among the available mathematical or statistical models, researchers used different metrics: Tobit model, Lerner index, Tobin model, Summary Innovation Index, Cragg test, European Innovation Scoreboard and Probit model. Although Oslo and Frascati manuals are constantly used on surveyed papers, only the research conducted by Chiang et al. (2012) used OECD criteria for obtaining innovation.

With respect to the financial metrics, selected researches showed that the profitability and performance have emerged as the most used measurement procedures.

Table 7 shows the distribution of researches in relation to the level of analysis for further discussion.

Table 7 Levels of analysis of the selected papers

\begin{tabular}{|c|c|c|}
\hline \multicolumn{2}{|c|}{ Level of analysis } & Authors \\
\hline \multicolumn{2}{|c|}{ Country } & $\begin{array}{l}\text { Hu and Mathews (2005), Bilbao-Osorio and Rodriguez-Pose } \\
\text { (2004), Grupp and Mogee (2004), Taylor (2009), Broberg et al. } \\
\text { (2013), Bavec (2009), Chan et al. (2011), Datta and Saad } \\
\text { (2011), Slaper et al. (2011) and Matei (2010) }\end{array}$ \\
\hline \multicolumn{2}{|l|}{ States } & Roper et al. (2010) \\
\hline \multicolumn{2}{|c|}{$\begin{array}{l}\text { Regions defined } \\
\text { geographically or regional } \\
\text { innovation systems }\end{array}$} & $\begin{array}{l}\text { Buesa et al. (2006), Fritsch and Slavtchev (2011), Kaasa } \\
\text { (2009), Falck et al. (2010), Rosenbloom (2007), Clark et al. } \\
\text { (2010), Ejermo (2009), Gonçalves and Almeida (2009), Zeng } \\
\text { et al. (2010), Chi and Qian (2010), Gumbau-Albert and Maudos } \\
\text { (2009) and Lee (2011) }\end{array}$ \\
\hline \multicolumn{2}{|c|}{$\begin{array}{l}\text { Meso-level } \\
\text { (inter-organisational levels) }\end{array}$} & Freel and de Jong (2009) \\
\hline Cities & & Therrien (2005) and Hsieh (2011) \\
\hline \multirow[t]{6}{*}{ Sector } & Furniture & Kaplinsky and Readman (2005) \\
\hline & Public area & Windrum and Garcia-Goni (2008) \\
\hline & $\begin{array}{l}\text { Information } \\
\text { technology }\end{array}$ & Yi et al. (2006) and Okon-Horodynska et al. (2011) \\
\hline & Servicing & $\begin{array}{l}\text { Camison and Monfort-Mir (2012), Hogan et al. (2011), } \\
\text { Hemphala and Magnusson (2012), Martino et al. (2012) and } \\
\text { Amore et al. (2013) }\end{array}$ \\
\hline & Energy & Noailly (2012) and Bettencourt et al. (2013) \\
\hline & High-tech & Guan and Chen (2010) \\
\hline Firm & & $\begin{array}{l}\text { Becker and Dietz (2004), Mansury and Love (2008), Czarnitzki } \\
\text { and Licht (2006), Tuominen et al. (2004), Persaud (2005), } \\
\text { Duysters and Lokshin (2011), Biscourp and Kramarz (2007), } \\
\text { Hirukawa and Ueda (2011), Blank and van Hulst (2009), } \\
\text { Collinson and Wang (2012), den Hertog et al. (2011), } \\
\text { Spithoven et al. (2010), van de Vrande et al. (2009), } \\
\text { Dervitsiotis (2011), Lamastra (2009), Leitner (2011), Yang and } \\
\text { Lin (2008), Aas and Pedersen (2011), Desmet et al. (2004), } \\
\text { Gotsch and Hipp (2012), Hsu and Chuang (2014), Lee and } \\
\text { Rugman (2012), Sepulveda et al. (2010) and Urgal e al. (2013). }\end{array}$ \\
\hline
\end{tabular}


Among the selected studies, the firm stands out as main level of analysis. This fact stems from the fact that the firm is responsible for adding value to the resources it receives and by selling them as products to the market. Owing to the objectivity of the metrics among resources (inputs) and products (outputs) of this production system, it is clear that the firm becomes an object of study to the researchers, which reinforces the microeconomic aspects of innovation metrics used in the selected researches.

Innovative performance metrics applied in a national level were also studied, as well as studies related to geographically defined regions. There is an interest in establishing innovation metrics in a country level reasoned by comparison needs of the most innovative countries, or even index indication that allow to rank the most innovative countries. The same applies to the regions, but those indexes are used as lobby for obtaining external financial resources for the development of cited region. It is noteworthy the conduction of researches in specific industries, each involving industries' specificities and metrics characteristics.

\section{Discussion and conclusions}

The establishment of metrics to measure innovation has always been and probably will always be difficult. This happens due largely to the different indicators required for implementation in different industries in addition to specific characteristics of each firm and their market.

With regard to quantitative analysis, it is noticed a significant growth of publications related to innovation metrics for the analysed period. Specifically, the most cited paper is of Lanjouw and Schankeman (2004), and scientific journals that have the highest number of selected publications were 'Research Policy' and 'Technovation' (both with high impact factors).

However, there are advances that go beyond the more traditional Oslo and Frascati manuals, consolidating in relation to patents measurement, performance, product and process innovations, inputs and outputs, innovative activities and capabilities, $R \& D$, and firm's structure and interactions. There are criticisms about the use of patents to measure innovation due having different degrees of importance across industries.

Regarding the level of analysis, we perceived that there is a concentration of metrics applied to, mainly, the microeconomic level (firms) and macroeconomic (country). We underline that there are some attempts to establish innovations measurement produced by geographically defined regions or by delimited economic sectors. Considering different industries, there are specificities that prevent the use of only one metric to derive innovation through other industries (cross-sectoral), such as Camison and Monfort-Mir (2012) and Brenner and Broekel (2011) state.

This research, as theoretical implications, sheds lights on actual state of the art of researches concerning innovation metrics to identify main terms beyond the known 'innovation indicators' terms. Through results, we identified the main methods present in literature to measure innovation that go beyond consolidated metric of number of patents, such as: performance measurements; product and process innovation; inputs and outputs; innovative activities; innovative capabilities; R\&D; and firm's structure and interactions (network). These metrics can help both researchers and practitioners to identify a set of innovative performance sources that could explain, in a broader sense, the contributive 
effect of these other innovation sources that contribute to the understanding of firm's innovative performance.

As limitations, this research focused on a specific period in time (last ten years period) and data collection was performed mainly in one scientific database (Web of Knowledge). Although we selected only one database, we chose one that included the majority of journals covering innovation and technology management themes.

We recommend future researches over a longer period to construct a path evolution of innovation metrics measures and the exploration in other scientific databases such as SCOPUS, Science Direct and ProQuest, to name a few, to establish a comparison with this research. For field researchers focused on innovation metrics thematic, we suggest future researches related to the meso-level (cities and regions levels) of innovation occurrence mainly in science-based industries whose innovation depends on partners' networks; and we suggest researches focusing intellectual property ownership in a context of open innovation. Finally, we expect that this study could stimulate bibliometric researches on innovation area by driving efforts to contribute to the advancement of metric studies of innovation.

\section{Acknowledgements}

The first author would like to thanks to CAPES for financial support through a scholarship. The authors thanks to the two anonymous reviewers and Editor of International Journal of Bibliometrics in Business and Management (IJBBM) for valuable contributions that improved the quality of this research paper.

\section{References}

Aas, T.H. and Pedersen, P.E. (2011) 'The impact of service innovation on firm-level financial performance', Service Industries Journal, Vol. 31, No. 13, pp.2071-2090 ISSN 0264-2069, Disponível em: go to ISI://WOS:000298923400002.

Abreu, M. et al. (2010) 'Policies to enhance the 'hidden innovation' in services: evidence and lessons from the UK', Service Industries Journal, Vol. 30, No. 1, pp.99-118, ISSN 02642069, Disponível em: go to ISI://WOS:000272209700008.

Adelman, D.E. and Deangelis, K.L. (2007) 'Patent metrics: the mismeasure of innovation in the biotech patent debate', Texas Law Review, June, Vol. 85, No. 7, pp.1677-1744, ISSN 00404411, Disponível em: go to ISI://WOS:000249052200003.

Alazzawi, S. (2012) 'Innovation, productivity and foreign direct investment-induced R\&D spillovers', Journal of International Trade \& Economic Development, Vol. 21, No. 5, pp.615-653, ISSN 0963-8199, Disponível em: go to ISI://WOS:000308033600001.

Albarrán, P., Ortuño, I. and Ruiz-Castillo, J. (2011) 'Average-based versus high- and low-impact indicators for the evaluation of scientific distributions', Research Evaluation, Vol. 20, No. 4 , pp.325-339.

Alegre, J., Chiva, R. and Lapiedra, R. (2009) 'Measuring innovation in long product development cycle industries: an insight in biotechnology', Technology Analysis \& Strategic Management, Vol. 21, No. 4, pp.535-546, ISSN 0953-7325, Disponível em: go to ISI://WOS:00026 5304100005 .

Altuzarra, A. and Serrano, F. (2010) 'Firms' innovation activity and numerical flexibility', Industrial \& Labor Relations Review, January, Vol. 63, No. 2, pp.327-339, ISSN 0019-7939, Disponível em: go to ISI://WOS:000273449000008. 
Amore, M.D., Schneider, C. and Zaldokas, A. (2013) 'Credit supply and corporate innovation', Journal of Financial Economics, September, Vol. 109, No. 3, pp.835-855, ISSN 0304-405X, Disponível em: go to ISI://WOS:000322358200013.

Antonelli, C. and Colombelli, A. (2011) 'The generation and exploitation of technological change: market value and total factor productivity', Journal of Technology Transfer, August, Vol. 36, No. 4, pp.353-382, ISSN 0892-9912, Disponível em: go to ISI://WOS:000292657800001.

Armbruster, H. et al. (2008) 'Organizational innovation: the challenge of measuring non-technical innovation in large-scale surveys', Technovation, October, Vol. 28, No. 10, pp.644-657, ISSN 0166-4972, Disponível em: go to ISI://WOS:000259729800002.

Aschhoff, B. and Schmidt, T. (2008) 'Empirical evidence on the success of R\&D cooperationhappy together?', Review of Industrial Organization, August, Vol. 33, No. 1, pp.41-62, ISSN 0889-938X, Disponível em: go to ISI://WOS:000260018600003.

Atrostic, B.K. (2008) 'Measuring U.S. innovative activity: business data at the U.S. Census Bureau', Journal of Technology Transfer, April, Vol. 33, No. 2, pp.153-171, ISSN 08929912, Disponível em: go to ISI://WOS:000259663200004.

Avermaete, T. et al. (2003) 'Determinants of innovation in small food firms', European Journal of Innovation Management, Vol. 6, No. 1, pp.8-17.

Baghele, O.N., Malpani, P.S. and Mohkhedkar, A.S. (2014) 'The 50 most cited manuscripts by Indian periodontists: a citation analysis of PubMed database', Oral Health and Dental Management, Vol. 13, No. 1, pp.137-145.

Bardin, L. (1977) Análise de conteúdo, p.70, Ediçõe, Lisboa.

Bavec, C. (2009) 'On the creative climate and innovativeness at the country level', Zbornik Radova Ekonomskog Fakulteta U Rijeci-Proceedings of Rijeka Faculty of Economics, September, Vol. 27, No. 1, pp.9-29, ISSN 1331-8004, Disponível em: go to ISI://WOS:000268624 100001 .

Becker, W. and Dietz, J. (2004) 'R\&D cooperation and innovation activities of firms - evidence for the German manufacturing industry', Research Policy, March, Vol. 33, No. 2, pp.209-223, ISSN 0048-7333, Disponível em: go to ISI://WOS:000220259600003.

Ben Rejeb, H. et al. (2008) 'Measuring innovation best practices: improvement of an innovation index integrating threshold and synergy effects', Technovation, December, Vol. 28, No. 12 , pp.838-854, ISSN 0166-4972, Disponível em: go to ISI://WOS:000261814300006.

Beneito, P. (2006) 'The innovative performance of in-house and contracted R\&D in terms of patents and utility models', Research Policy, May, Vol. 35, No. 4, pp.502-517, ISSN 00487333, Disponível em: go to ISI://WOS:000237772700003.

Bettencourt, L.M.A., Trancik, J.E. and Kaur, J. (2013) 'Determinants of the pace of global innovation in energy technologies', Plos One, October, Vol. 8, No. 10, pp.1-6, ISSN 19326203, Disponível em: go to ISI://WOS:000325887300001.

Bilbao-Osorio, B. and Rodriguez-Pose, A. (2004) 'From R\&D to innovation and economic growth in the EU', Growth and Change, September, Vol. 35, No. 4, pp.434-455, ISSN 0017-4815, Disponível em: go to ISI://WOS:000224654600002.

Birchall, D. et al. (2011) 'Innovation performance measurement: current practices, issues and management challenges', International Journal of Technology Management, Vol. 56, No. 1, pp.1-20, ISSN 0267-5730, Disponível em: go to ISI://WOS:000294951500001.

Biscourp, P. and Kramarz, F. (2007) 'Employment, skill structure and international trade: firm-level evidence for France', Journal of International Economics, May, Vol. 72, No. 1, pp.22-51, ISSN 0022-1996, Disponível em: go to ISI://WOS:000246322600002.

Blank, J.L.T. and van Hulst, B.L. (2009) 'Productive innovations in hospitals: an empirical research on the relation between technology and productivity in the Dutch hospital industry', Health Economics, June, Vol. 18, No. 6, pp.665-679, ISSN 1057-9230, Disponível em: go to ISI://WOS:000266353700004. 
Borgman, C.L. and Furner, J. (2002) Scholarly Communication and Bibliometrics, UCLA, Los Angeles [online] http://polaris.gseis.ucla.edu/gleazer/296_readings/arist02.pdf (accessed November 2014).

Brenner, T. and Broekel, T. (2011) 'Methodological issues in measuring innovation performance of spatial units', Industry and Innovation, Vol. 18, No. 1, pp.7-37, ISSN 1366-2716, Disponível em: go to ISI://WOS:000285349000002.

Broberg, J.C. et al. (2013) 'Political institutional structure influences on innovative activity', Journal of Business Research, December, Vol. 66, No. 12, pp.2574-2580, ISSN 0148-2963, Disponível em: go to ISI://WOS:000326214300029.

Bruni, A.Z. (2008) Estatística aplicada à gestão empresarial, 2nd ed., Atlas, São Paulo.

Buesa, M. et al. (2006) 'Regional systems of innovation and the knowledge production function: the Spanish case', Technovation, April, Vol. 26, No. 4, pp.463-472, ISSN 0166-4972, Disponível em: go to ISI://WOS:000236306600003.

Camison, C. and Monfort-Mir, V.M. (2012) 'Measuring innovation in tourism from the Schumpeterian and the dynamic-capabilities perspectives', Tourism Management, August, Vol. 33, No. 4, pp.776-789, ISSN 0261-5177, Disponível em: go to ISI://WOS:0003013 09500005 .

Campbell, S. et al. (2009) 'Informing public policy on science and innovation: the advanced technology program's experience', Journal of Technology Transfer, June, Vol. 34, No. 3, pp.304-319, ISSN 0892-9912, Disponível em: go to ISI://WOS:000263181400004.

Castellacci, F. and Miguel Natera, J. (2013) 'The dynamics of national innovation systems: a panel cointegration analysis of the coevolution between innovative capability and absorptive capacity', Research Policy, April, Vol. 42, No. 3, pp.579-594, ISSN 0048-7333, Disponível em: go to ISI://WOS:000317025200001.

Catapan, A. and Cherobim, A.P.M.S. (2010) 'Estado da arte da governança corporative: estudo bibliométrico nos anos de 2000 a 2010', Race, Vol. 9, Nos. 1-2, pp.207-230.

Chan, K-Y. A., Oerlemans, L.A.G. and Pretorius, M.W. (2011) 'Innovation outcomes of South African new technology-based firms: a contribution to the debate on the performance of science park firms', South African Journal of Economic and Management Sciences, Vol. 14, No. 4, pp.361-378, ISSN 1015-8812, Disponível em: go to ISI://WOS:000299678800001.

Cheng, C.J. and Shiu, E.C.C. (2008) 'Re-innovation: the construct, measurement, and validation', Technovation, October, Vol. 28, No. 10, pp.658-666, ISSN 0166-4972, Disponível em: go to ISI://WOS:000259729800003.

Chi, W. and Qian, X. (2010) 'The role of education in regional innovation activities: spatial evidence from China', Journal of the Asia Pacific Economy, Vol. 15, No. 4, pp.396-419, ISSN 1354-7860, Disponível em: go to ISI://WOS:000283887000006.

Chiang, S., Lee, P. and Anandarajan, A. (2012) 'The effect of R\&D tax credit on innovation: a life cycle analysis', Innovation-Management Policy \& Practice, December, Vol. 14, No. 4, pp.510-523, ISSN 1447-9338, Disponível em: go to ISI://WOS:000314931300003.

Christensen, C.M. (1999) Innovation and the General Management, Irwin McGraw-Hill, Boston.

Christensen, C.M. (2004) Seeing What's Next: Using the Theories of Innovation to Predict Industry Change, Harvard Business School Press, Boston.

Christensen, C.M. and Raynor, M.E. (2003) The Innovator's Solution: Creating and Sustaining Successful Growth, Harvard Business School Press, Boston.

Clark, J., Huang, H-I. and Walsh, J.P. (2010) 'A typology of 'innovation districts': what it means for regional resilience', Cambridge Journal of Regions Economy and Society, March, Vol. 3, No. 1, pp.121-137, ISSN 1752-1378, Disponível em: go to ISI://WOS:000292153800009.

Clausen, T. et al. (2012) 'Innovation strategies as a source of persistent innovation', Industrial and Corporate Change, June, Vol. 21, No. 3, pp.553-585, ISSN 0960-6491, Disponível em: go to ISI://WOS:000304531400002. 
Collinson, S.C. and Wang, R. (2012) 'The evolution of innovation capability in multinational enterprise subsidiaries: dual network embeddedness and the divergence of subsidiary specialisation in Taiwan', Research Policy, November, Vol. 41, No. 9, pp.1501-1518, ISSN 0048-7333, Disponível em: go to ISI://WOS:000309901700001.

Conte, A. (2009) 'Mapping innovative activity using microdata', Applied Economics Letters, Vol. 16, No. 18, pp.1795-1799, ISSN 1350-4851, Disponível em: go to ISI://WOS:00027 2138800004.

Cowan, R., Jonard, N. and Ozman, M. (2004) 'Knowledge dynamics in a network industry', Technological Forecasting and Social Change, June, Vol. 71, No. 5, pp.469-484, ISSN 00401625, Disponível em: go to ISI://WOS:000221063100003.

Crosby, M. (2000) 'Patents, innovation and growth', Economic Record, Vol. 76, No. 234, pp.255-262.

Cross, R. et al. (2006) 'Using social network analysis to improve communities of practice', California Management Review, Fall, Vol. 49, No. 1, 32, ISSN 0008-1256, Disponível em: go to ISI://WOS:000242183500003.

Cruz-Cázares, C., Bayona-Saez, C. and Garcia-Marco, T. (2013) 'You can't manage right what you can't measure well: technological innovation efficiency', Research Policy, July-August, Vol. 42, Nos. 6-7, pp.1239-1250, ISSN 0048-7333, Disponível em: go to ISI://WOS:000 321604200009 .

Czarnitzki, D. and Licht, G. (2006) 'Additionality of public R\&D grants in a transition economy', Economics of Transition, Vol. 14, No. 1, pp.101-131, ISSN 0967-0750, Disponível em: go to ISI://WOS:000234974500004.

Datta, S. and Saad, M. (2011) 'University and innovation systems: the case of India', Science and Public Policy, February, Vol. 38, No. 1, pp.7-17, ISSN 0302-3427, Disponível em: go to ISI://WOS:000294372200002.

de Winne, S. and Sels, L. (2010) 'Interrelationships between human capital, HRM and innovation in Belgian start-ups aiming at an innovation strategy', International Journal of Human Resource Management, Vol. 21, No. 11, pp.1863-1883, ISSN 0958-5192, Disponível em: go to ISI://WOS:000282581600004.

den Butter, F.A.G., Mohlmann, J.L. and Wit, P. (2008) 'Trade and product innovations as sources for productivity increases: an empirical analysis', Journal of Productivity Analysis, December, Vol. 30, No. 3, pp.201-211, ISSN 0895-562X, Disponível em: go to ISI://WOS:000260 067500004 .

den Hertog, P., Gallouj, F. and Segers, J. (2011) 'Measuring innovation in a 'low-tech' service industry: the case of the Dutch hospitality industry', Service Industries Journal, Vol. 31, No. 9, pp.1429-1449, ISSN 0264-2069, Disponível em: go to ISI://WOS:000290676000004.

Dervitsiotis, K.N. (2011) 'The challenge of adaptation through innovation based on the quality of the innovation process', Total Quality Management \& Business Excellence, Vol. 22, No. 5, pp.553-566, ISSN 1478-3363, Disponível em: go to ISI://WOS:000291091300005.

Desmet, K., Kujal, P. and Lobo, F. (2004) 'Implementing R\&D policies: an analysis of Spain's pharmaceutical research program', Research Policy, December, Vol. 33, No. 10, pp.1493-1507, ISSN 0048-7333, Disponível em: go to ISI://WOS:000226708200004.

Desouza, K.C. et al. (2009) 'Crafting organizational innovation processes', InnovationManagement Policy \& Practice, Vol. 11, No. 1, pp.6-33, ISSN 1447-9338, Disponível em: go to ISI://WOS:000279054700002.

Dibrell, C., Davis, P.S. and Craig, J. (2008) 'Fueling innovation through information technology in SMEs', Journal of Small Business Management, April, Vol. 46, No. 2, pp.203-218, ISSN 0047-2778, Disponível em: go to ISI://WOS:000254415700003.

Duysters, G. and Lokshin, B. (2011) 'Determinants of alliance portfolio complexity and its effect on innovative performance of companies', Journal of Product Innovation Management, July, Vol. 28, No. 4, pp.570-585, ISSN 0737-6782, Disponível em: go to ISI://WOS:000290 448900010 . 
Edison, H., Bin Ali, N. and Torkar, R. (2013) 'Towards innovation measurement in the software industry', Journal of Systems and Software, May, Vol. 86, No. 5, pp.1390-1407, ISSN 01641212, Disponível em: go to ISI://WOS:000317322400017.

Eisenhardt, K.M. and Tabrizi, B.N. (1995) 'Accelerating adaptive processes: product innovation in the global computer industry', Administrative Science Quarterly, Vol. 40, No. 1, pp.84-110.

Ejermo, O. (2009) 'Regional innovation measured by patent data-does quality matter? Industry and innovation, Industry and Innovation April, Vol. 16, No. 2, pp.141-165, ISSN 1366-2716, Disponível em: go to ISI://WOS:000268240400001.

Falck, O., Heblich, S. and Kipar, S. (2010) 'Industrial innovation: direct evidence from a cluster-oriented policy', Regional Science and Urban Economics, November, Vol. 40, No. 6, pp.574-582, ISSN 0166-0462, Disponível em: go to ISI://WOS:000285445700017.

Ferasso, M. (2013) Knowledge Creation within Enterprises of Industrial Clusters: Multi Case Studies from French and Brazilian Biotechs, Lambert Academic Publishing, Saarbrücken.

Freel, M. and de Jong, J.P.J. (2009) 'Market novelty, competence-seeking and innovation networking', Technovation, December, Vol. 29, No. 12, pp.873-884, ISSN 0166-4972, Disponível em: go to ISI://WOS:000271713400007.

Freel, M.S. (2007) 'Are small innovators credit rationed?', Small Business Economics, January, Vol. 28, No. 1, pp.23-35, ISSN 0921-898X, Disponível em: go to ISI://WOS:00024 3691600002.

Freel, M.S. and Robson, P.J. (2004) 'A small firm innovation, growth and performance - evidence from Scotland and Northern England', International Small Business Journal, December, Vol. 22, No. 6, pp.561-575, ISSN 0266-2426, Disponível em: go to ISI://WOS:00022 5724400002 .

Fritsch, M. and Slavtchev, V. (2011) 'Determinants of the efficiency of regional innovation systems', Regional Studies, Vol. 45, No. 7, pp.905-918, ISSN 0034-3404, Disponível em: go to ISI://WOS:000292922700003.

Garcia, C.Q. and Velasco, C.A.B. (2008) 'Configuration of the tecnological portfolio, diversity and innovation: a longitudinal study', Cuadernos De Economia Y Direccion De La Empresa, Vol. 11, No. 34, pp.53-80, ISSN 1138-5758, Disponível em: go to ISI://WOS:00026 2939700003.

Geisler, E. (2000) The Metrics of Science and Technology, Quorum Books, Westport.

Ghazalian, P.L. and Furtan, W.H. (2007) 'The effect of innovation on agricultural and agri-food exports in OECD countries', Journal of Agricultural and Resource Economics, December, Vol. 32, No. 3, pp.448-461, ISSN 0162-1912, Disponível em: go to ISI://WOS:000251 680100004

Ghinamo, M.L. (2012) 'Explaining the variation in the empirical estimates of academic knowledge spillovers', Journal of Regional Science, October, Vol. 52, No. 4, pp.606-634, ISSN 00224146, Disponível em: go to ISI://WOS:000309068800004.

Gittelman, M. (2008) 'The value of European patents', European Management Review, Summer, Vol. 5, No. 2, pp.85-89, ISSN 1740-4754, Disponível em: go to ISI://WOS:0002086778 00003 .

Gonçalves, E. and Almeida, E. (2009) 'Innovation and spatial knowledge spillovers: evidence from Brazilian patent data', Regional Studies, Vol. 43, No. 4, pp.513-528, ISSN 0034-3404, Disponível em: go to ISI://WOS:000265868000001.

Gorodnichenko, Y. and Schnitzer, M. (2013) 'Financial constraints and innovation: why poor countries don't catch up', Journal of the European Economic Association, October, Vol. 11, No. 5, pp.1115-1152, ISSN 1542-4766, Disponível em: go to ISI://WOS:000324310200006.

Gotsch, M. and Hipp, C. (2012) 'Measurement of innovation activities in the knowledge-intensive services industry: a trademark approach', Service Industries Journal, Vol. 32, No. 13, pp.2167-2184, ISSN 0264-2069, Disponível em: go to ISI://WOS:000307347300008. 
Govindarajan, V. and Kopalle, P.K. (2006) 'Disruptiveness of innovations: measurement and an assessment of reliability and validity', Strategic Management Journal, February, Vol. 27, No. 2, pp.189-199, ISSN 0143-2095, Disponível em: go to ISI://WOS:000234869500005.

Graebner, M.E. (2004) 'Momentum and serendipity: how acquired leaders create value in the integration of technology firms', Strategic Management Journal, Vol. 25, Nos. 8-9, pp.751-777.

Grupp, H. and Mogee, M.E. (2004) 'Indicators for national science and technology policy: how robust are composite indicators?', Research Policy, November, Vol. 33, No. 9, pp.1373-1384, ISSN 0048-7333, Disponível em: go to ISI://WOS:000226145600007.

Guan, J. and Chen, K. (2010) 'Measuring the innovation production process: a cross-region empirical study of China's high-tech innovations', Technovation, May-June, Vol. 30, Nos. 5-6, pp.348-358, ISSN 0166-4972, Disponível em: go to ISI://WOS:000278202900006.

Gumbau-Albert, M. and Maudos, J. (2009) 'Patents, technological inputs and spillovers among regions', Applied Economics, Vol. 41, No. 12, pp.1473-1486, ISSN 0003-6846, Disponível em: go to ISI://WOS:000265631300002.

Hall, B.H. et al. (2013) 'The importance (or not) of patents to UK firms', Oxford Economic PapersNew Series, July, Vol. 65, No. 3, p. 603-629, ISSN 0030-7653, Disponível em: go to ISI://WOS:000321098400003.

Hall, J.L. (2007) 'Developing historical 50-state indices of innovation capacity and commercialization capacity', Economic Development Quarterly, May, Vol. 21, No. 2, pp.107-123, ISSN 0891-2424, Disponível em: go to ISI://WOS:000245893500001.

Hamamoto, M. (2006) 'Environmental regulation and the productivity of Japanese manufacturing industries', Resource and Energy Economics, November, Vol. 28, No. 4, pp.299-312, ISSN 0928-7655, Disponível em: go to ISI://WOS:000242038200001.

Hemphala, J. and Magnusson, M. (2012) 'Networks for innovation - but what networks and what innovation?', Creativity and Innovation Management, March, Vol. 21, No. 1, pp.3-16, ISSN 0963-1690, Disponível em: go to ISI://WOS:000300680000002.

Hirsch, J.E. (2005) 'An index to quantify an individual's scientific research output', PNAS, Vol. 102, No. 46, pp.16569-16572.

Hirsch, J.E. (2007) 'Does the $\mathrm{h}$ index have predictive power?', PNAS, Vol. 104, No. 49, pp.19193-19198.

Hirukawa, M. and Ueda, M. (2011) 'Venture capital and innovation: which is first?', Pacific Economic Review, October, Vol. 16, No. 4, pp.421-465, ISSN 1361-374X, Disponível em: go to ISI://WOS:000296045900002.

Ho, Y-Y. (2007) 'Bibliometric analysis of adsorption technology in environmental science', Journal of Environmental Protection Science, Vol. 1, No. 1, pp.1-11.

Hogan, S.J. et al. (2011) 'Reconceptualizing professional service firm innovation capability: scale development', Industrial Marketing Management, November, Vol. 40, No. 8, pp.1264-1273, ISSN 0019-8501, Disponível em: go to ISI://WOS:000298942200006.

Hsieh, J.Y. (2011) 'A multilevel growth assessment of the diffusion of management innovation nested in state levels: the case of US local economic development programs', InnovationManagement Policy \& Practice, April, Vol. 13, No. 1, pp.2-19, ISSN 1447-9338, Disponível em: go to ISI://WOS:000294125900001.

Hsu, J. and Chuang, Y-P. (2014) 'International technology spillovers and innovation: evidence from Taiwanese high-tech firms', Journal of International Trade \& Economic Development, April, Vol. 23, No. 3, pp.387-401, ISSN 0963-8199, Disponível em: go to ISI://WOS:0003 29962700004.

Hu, M.C. and Mathews, J.A. (2005) 'National innovative capacity in East Asia', Research Policy, November, Vol. 34, No. 9, pp.1322-1349, ISSN 0048-7333, Disponível em: go to ISI://WOS:000233610800003. 
Hu, M-C. and Mathews, J.A. (2009) 'Estimating the innovation effects of university-industrygovernment linkages: the case of Taiwan', Journal of Management \& Organization, May, Vol. 15, No. 2, pp.138-154, ISSN 1833-3672, Disponível em: go to ISI://WOS:000 266843300001 .

Jalles, J.T. (2010) 'How to measure innovation? New evidence of the technology-growth linkage', Research in Economics, Vol. 64, No. 2, pp.81-96.

Jayanthi, S., Witt, E.C. and Singh, V. (2009) 'Evaluation of potential of innovations: a DEA-based application to US photovoltaic industry', IEEE Transactions on Engineering Management, August, Vol. 56, No. 3, pp.478-493, ISSN 0018-9391, Disponível em: go to ISI://WOS: 000268281600009 .

Jensen, P.H. and Webster, E. (2009) 'Another look at the relationship between innovation proxies', Australian Economic Papers, September, Vol. 48, No. 3, pp.252-269, ISSN 0004-900X, Disponível em: go to ISI://WOS:000269800800005.

Kaasa, A. (2009) 'Effects of different dimensions of social capital on innovative activity: evidence from Europe at the regional level', Technovation, March, Vol. 29, No. 3, pp.218-233, ISSN 0166-4972, Disponível em: go to ISI://WOS:000264619700006.

Kaplinsky, R. and Readman, J. (2005) 'Globalization and upgrading: what can (and cannot) be learnt from international trade statistics in the wood furniture sector?', Industrial and Corporate Change, August, Vol. 14, No. 4, pp.679-703, ISSN 0960-6491, Disponível em: go to ISI://WOS:000231324300006.

Katila, R. (2000) 'Using patent data to measure innovation performance', International Journal of Business Performance Management, Vol. 2, Nos. 1-3, pp.180-193.

Kim, S.K. et al. (2011) 'The effect of R\&D, technology commercialization capabilities and innovation performance', Technological and Economic Development of Economy, December, Vol. 17, No. 4, pp.563-578, ISSN 1392-8619, Disponível em: go to ISI:/WOS:00029 8775300001 .

Klas, A. (2010) 'Research as the factor of innovative development', Ekonomicky Casopis, Vol. 58, No. 9, pp.871-887, ISSN 0013-3035, Disponível em: go to ISI://WOS:000286502600001.

Kleinknecht, A., van Montfort, K. and Brouwer, E. (2002) 'The non-trivial choice between innovation indicators', Economics of Innovation and New Technology, Vol. 11, No. 2, pp.109-121.

Lachenmaier, S. and Rottmann, H. (2011) 'Effects of innovation on employment: a dynamic panel analysis', International Journal of Industrial Organization, March, Vol. 29, No. 2, pp.210-220, ISSN 0167-7187, Disponível em: go to ISI://WOS:000288471900006.

Lamastra, C.R. (2009) 'Software innovativeness. A comparison between proprietary and free/open source solutions offered by Italian SMEs', $R \& D$ Management, March, Vol. 39, No. 2, pp.153-169, ISSN 0033-6807, Disponível em: go to ISI://WOS:000263328300004.

Lanjouw, J.O. and Schankeman, M. (2004) 'Patent quality and research productivity: measuring innovation with multiple indicators', Economic Journal, April, Vol. 114, No. 495, pp.441-465, ISSN 0013-0133, Disponível em: go to ISI://WOS:000221058500011.

Lee, I.H. and Rugman, A.M. (2012) 'Firm-specific advantages, inward FDI origins, and performance of multinational enterprises', Journal of International Management, June, Vol. 18, No. 2, pp.132-146, ISSN 1075-4253, Disponível em: go to ISI:/WOS:000 303817400002 .

Lee, N. (2011) 'Are innovative regions more unequal? Evidence from Europe', Environment and Planning C-Government and Policy, Vol. 29, No. 1, pp.2-23, ISSN 0263-774X. Disponível em: go to ISI://WOS:000301179700001.

Lee, Y-G., Park, S-H. and Song, Y-I. (2009) 'Which is better for a firm's financial performance: an externally oriented or inwardly oriented innovation strategy? An Empirical study on Korean SMEs', Asian Journal of Technology Innovation, July, Vol. 17, No. 1, pp.57-73, ISSN 19761597, Disponível em: go to ISI://WOS:000269661900004. 
Leitner, K-H. (2011) 'The effect of intellectual capital on product innovativeness in SMEs', International Journal of Technology Management, Vol. 53, No. 1, pp.1-17, ISSN 0267-5730, Disponível em: go to ISI://WOS:000285094000001.

Lerner, J., Sorensen, M. and Stroemberg, P. (2011) 'Private equity and long-run investment: the case of innovation', Journal of Finance, April, Vol. 66, No. 2, pp.445-477, ISSN 0022-1082, Disponível em: go to ISI://WOS:000288661100004.

Lim, K. (2004) 'The relationship between research and innovation in the semiconductor and pharmaceutical industries (1981-1997)', Research Policy, Vol. 33, No. 2, pp.287-321.

Lin, C. et al. (2011) 'Managerial incentives, CEO characteristics and corporate innovation in China's private sector', Journal of Comparative Economics, June, Vol. 39, No. 2, pp.176-190, ISSN 0147-5967, Disponível em: go to ISI://WOS:000292366300004.

Lin, H-L. and Lin, E.S. (2010) 'FDI, trade, and product innovation: theory and evidence', Southern Economic Journal, October, Vol. 77, No. 2, pp.434-464, ISSN 0038-4038, Disponível em: go to ISI://WOS:000283026300010.

Mansury, M.A. and Love, J.H. (2008) 'Innovation, productivity and growth in US business services: a firm-level analysis', Technovation, January-February, Vol. 28, Nos. 1-2, pp.52-62, ISSN 0166-4972, Disponível em: go to ISI://WOS:000252606700005.

Martino, O.I. et al. (2012) 'Innovation and the burden of disease: retrospective observational study of new and emerging health technologies reported by the EuroScan network from 2000 to 2009', Value in Health, March-April, Vol. 15, No. 2, pp.376-380, ISSN 1098-3015, Disponível em: go to ISI://WOS:000301930600020.

Matei, M. (2010) 'Innovation efficiency analysis for Romania', Economic Computation and Economic Cybernetics Studies and Research, Vol. 44, No. 3, pp.193-204, ISSN 0424-267X, Disponível em: go to ISI://WOS:000281508500014.

Matolcsy, Z.R. and Wyatt, A. (2008) 'The association between technological conditions and the market value of equity', Accounting Review, March, Vol. 83, No. 2, pp.479-518, ISSN 00014826, Disponível em: go to ISI://WOS:000254412500008.

Mazzucato, M. and Tancioni, M. (2012) 'R\&D, patents and stock return volatility', Journal of Evolutionary Economics, September, Vol. 22, No. 4, pp.811-832, ISSN 0936-9937, Disponível em: go to ISI://WOS:000308250100009.

Melnyk, S.A., Hanson, J.D. and Calantone, R.J. (2010) 'Hitting the target ... but missing the point: resolving the paradox of strategic transition', Long Range Planning, August, Vol. 43, No. 4, pp.555-574, ISSN 0024-6301, Disponível em: go to ISI://WOS:000281319100006.

Moed, H.F. et al. (1985) 'The use of bibliometric data for the measurement of university research performance', Research Policy, Vol. 14, No. 3, pp.131-149.

Montresor, S. and Marzetti, G.V. (2009) 'Applying social network analysis to input-output based innovation matrices: an illustrative application to six OECD technological systems for the middle 1990s', Economic Systems Research, Vol. 21, No. 2, pp.129-149, ISSN 0953-5314, Disponível em: go to ISI://WOS:000273938700003.

Narin, F. (1976) Evaluative bibliometrics: the use of publication and citation analysis in the evaluation of scientific activity, Computer Horizons Inc, New Jersey [online] http://yunus.hacettepe.edu.tr/ tonta/courses/spring2011/bby704/narin_1975_evalbibliometrics_images.pdf (accessed November 2014).

Noailly, J. (2012) 'Improving the energy efficiency of buildings: the impact of environmental policy on technological innovation', Energy Economics, May, Vol. 34, No. 3, pp.795-806, ISSN 0140-9883, Disponível em: go to ISI://WOS:000304513500017.

O'neale, D.R.J. and Hendy, S.C. (2012) 'Power law distributions of patents as indicators of innovation', Plos One, December, Vol. 7, No. 12, pp.1-9, ISSN 1932-6203, Disponível em: go to ISI://WOS:000312588200007.

OECD (2005) Oslo Manual, 3rd ed. [online] http://www.oecd.org/science/inno/2367580.pdf (accessed November 2014). 
OECD (2007) Manual de Frascati [online] http://unstats.un.org/unsd/EconStatKB/ Attachment328.aspx (accessed November 2014).

Okon-Horodynska, E., Wisla, R. and Sierotowicz, T. (2011) 'Evaluation of the development potential of the information society in European Union countries on the basis of patent activity in the ICT sector', Transformations in Business \& Economics, Vol. 10, No. 2A, pp.452-462, ISSN 1648-4460, Disponível em: go to ISI://WOS:000297658500022.

Persaud, A. (2005) 'Enhancing synergistic innovative capability in multinational corporations: an empirical investigation', Journal of Product Innovation Management, September, Vol. 22, No. 5, pp.412-429, ISSN 0737-6782, Disponível em: go to ISI://WOS:000231261800005.

Prajogo, D.I. and Sohal, A.S. (2006) 'The relationship between organization strategy, total quality management (TQM), and organization performance - the mediating role of TQM', European Journal of Operational Research, January, Vol. 168, No. 1, pp.35-50, ISSN 0377-2217, Disponível em: go to ISI://WOS:000231848200003.

Radicchi, F., Fortunato, S. and Castellano, C. (2008) 'Universality of citation distributions: toward an objective measure of scientific impact', Proceedings of the National Academy of Sciences, Vol. 105, No. 45, pp.17268-17272.

Roper, S. et al. (2010) 'Knowledge, capabilities and manufacturing innovation: a USA-Europe comparison', Regional Studies, Vol. 44, No. 3, pp.253-279, ISSN 0034-3404, Disponível em: go to ISI://WOS:000276032700002.

Rosenbloom, J.L. (2007) 'The geography of innovation commercialization in the United States during the 1990s', Economic Development Quarterly, February, Vol. 21, No. 1, pp.3-16, ISSN 0891-2424, Disponível em: go to ISI://WOS:000243809500001.

Saguy, S. et al. (2013) 'Challenges facing food engineering', Journal of Food Engineering, Vol. 119, No. 2, pp.332-342.

Sakakibara, M. and Branstetter, L. (1999) Do Stronger Patents Induce More Innovation? Evidence from the 1998 Japanese Patent Law Reforms, NBER Working paper series, National Bureau of Economic Research, Cambridge [online] http://www.nber.org/papers/w7066.pdf (accessed November 2014).

Santarelli, E. and Lotti, F. (2008) 'Innovative output, productivity and profitability. A test comparing USPTO and EPO data', Industry and Innovation, Vol. 15, No. 4, pp.393-409, ISSN 1366-2716, Disponível em: go to ISI://WOS:000263297600003.

Saunila, M. and Ukko, J. (2012) 'A conceptual framework for the measurement of innovation capability and its effects', Baltic Journal of Management, Vol. 7, No. 4, pp.355-375, ISSN 1746-5265, Disponível em: go to ISI://WOS:000312474600002.

Schumpeter, J.A. (1934) The Theory of Economic Development: An Inquiry into Profits, Capital, Credit, Interest and the Business Cycle, Transaction Publishers, New Brunswick.

Sepulveda, J. et al. (2010) 'A metrics-based diagnosis tool for enhancing innovation capabilities in SMEs', International Journal of Computers Communications \& Control, December, Vol. 5, No. 5, pp.919-928, ISSN 1841-9836, Disponível em: go to ISI://WOS:000283908700035.

Seru, A. (2014) 'Firm boundaries matter: evidence from conglomerates and R\&D activity', Journal of Financial Economics, February, Vol. 111, No. 2, pp.381-405, ISSN 0304-405X, Disponível em: go to ISI://WOS:000330486100006.

Slaper, T.F. et al. (2011) 'The index of innovation: a new tool for regional analysis', Economic Development Quarterly, February, Vol. 25, No. 1, pp.36-53, ISSN 0891-2424, Disponível em: go to ISI://WOS:000285767500004.

Sorescu, A.B. and Spanjol, J. (2008) 'Innovation's effect on firm value and risk: insights from consumer packaged goods', Journal of Marketing, March, Vol. 72, No. 2, pp.114-132, ISSN 0022-2429, Disponível em: go to ISI://WOS:000254009400011.

Spithoven, A., Frantzen, D. and Clarysse, B. (2010) 'Heterogeneous firm-level effects of knowledge exchanges on product innovation: differences between dynamic and lagging product innovators', Journal of Product Innovation Management, May, Vol. 27, No. 3, pp.362-381, ISSN 0737-6782, Disponível em: go to ISI://WOS:000275886000005. 
Stiebale, J. and Reize, F. (2011) 'The impact of FDI through mergers and acquisitions on innovation in target firms', International Journal of Industrial Organization, March, Vol. 29, No. 2, pp.155-167, ISSN 0167-7187, Disponível em: go to ISI://WOS:000288471900001.

Stuart, T.E. (2000) 'Interorganizational alliances and the performance of firms: a study of growth and innovation rates in a high-technology industry', Strategic Management Journal, Vol. 21, No. 8, pp.791-811.

Szymanski, D.M., Kroff, M.W. and Troy, L.C. (2007) 'Innovativeness and new product success: insights from the cumulative evidence', Journal of the Academy of Marketing Science, March, Vol. 35, No. 1, pp.35-52, ISSN 0092-0703, Disponível em: go to ISI://WOS:000246619 000004 .

Taylor, M.Z. (2009) 'International linkages and national innovation rates: an exploratory probe', Review of Policy Research, January-March, Vol. 26, Nos. 1-2, pp.127-149, ISSN 1541-132X, Disponível em: go to ISI://WOS:000282919000007.

Therrien, P. (2005) 'City and innovation: different size, different strategy', European Planning Studies, September, Vol. 13, No. 6, pp.853-877, ISSN 0965-4313, Disponível em: go to ISI://WOS:000231479900004.

Thomae, J. and Bizer, K. (2013) 'To protect or not to protect? Modes of appropriability in the small enterprise sector', Research Policy, February, Vol. 42, No. 1, pp.35-49, ISSN 0048-7333, Disponível em: go to ISI://WOS:000313374400004.

Tsai, C.T. et al. (2005) 'An integration framework of innovation assessment for the knowledgeintensive service industry', International Journal of Technology Management, Vol. 30, Nos. 1-2, pp.85-104, ISSN 0267-5730, Disponível em: go to ISI://WOS:000228167700006.

Tuominen, M., Rajala, A. and Moller, K. (2004) 'How does adaptability drive firm innovativeness?', Journal of Business Research, May, Vol. 57, No. 5, pp.495-506, ISSN 0148-2963, Disponível em: go to ISI://WOS:000220514200005.

Ughetto, E. (2008) 'Does internal finance matter for R\&D? New evidence from a panel of Italian firms', Cambridge Journal of Economics, November, Vol. 32, No. 6, pp.907-925, ISSN 0309166X, Disponível em: go to ISI://WOS:000260553300004.

Ughetto, E. (2010) 'Assessing the contribution to innovation of private equity investors: a study on European buyouts', Research Policy, February, Vol. 39, No. 1, pp.126-140, ISSN 0048-7333, Disponível em: go to ISI://WOS:000274958400012.

Urgal, B., Quintas, M.A. and Arevalo Tome, R. (2011) 'Technological knowledge, innovation capability and innovative performance: the moderating role of the behavioural environment of the firm', Cuadernos De Economia Y Direccion De La Empresa, January-March, Vol. 14, No. 1, pp.53-66, ISSN 1138-5758, Disponível em: go to ISI://WOS:000291297800006.

Urgal, B., Quintas, M.A., and Arevalo-Tome, R. (2013) 'Knowledge resources and innovation performance: the mediation of innovation capability moderated by management commitment', Technology Analysis \& Strategic Management, May, Vol. 25, No. 5, pp.543-565, ISSN 09537325, Disponível em: go to ISI://WOS:000318282100004.

Utterback, J.M. and Acee, H.J. (2005) 'Disruptive technologies: an expanded view', International Journal of Innovation Management, Vol. 9, No. 1, pp.1-17.

van Beveren, I. and van den Bussche, H. (2010) 'Product and process innovation and firms' decision to export', Journal of Economic Policy Reform, Vol. 13, No. 1, pp.3-24, ISSN 17487870, Disponível em: go to ISI://WOS:000274551600002.

van de Vrande, V. et al. (2009) 'Open innovation in SMEs: trends, motives and management challenges', Technovation, June-July, Vol. 29, Nos. 6-7, pp.423-437, ISSN 0166-4972, Disponível em: go to ISI://WOS:000266760900003.

Voss, C.A. (1992) 'Measurement of innovation and design performance in services', Desing Management Journal, Vol. 3, No. 1, pp.40-46. 
Walter, A. et al. (2011) 'Championship behaviors and innovations success: an empirical investigation of university spin-offs', Journal of Product Innovation Management, July, Vol. 28, No. 4, pp.586-598, ISSN 0737-6782, Disponível em: go to ISI://WOS:000290 448900011.

Werner, B. and Souder, W. (1997) 'Measuring R\&D performance: state of the art', ResearchTechnology Management, Vol. 40, No. 2, pp.34-42.

Windrum, P. and Garcia-Goni, M. (2008) 'A neo-Schumpeterian model of health services innovation', Research Policy, May, Vol. 37, No. 4, pp.649-672, ISSN 0048-7333, Disponível em: go to ISI://WOS:000255810800006.

Wong, A., Tjosvold, D. and Liu, C. (2009) 'Innovation by teams in Shanghai, China: cooperative goals for group confidence and persistence', British Journal of Management, June, Vol. 20, No. 2, pp.238-251, ISSN 1045-3172, Disponível em: go to ISI://WOS:000265934200007.

Yang, C-H. and Lin, C-H.A. (2008) 'Developing employment effects of innovations: microeconometric evidence from Taiwan', Developing Economies, June, Vol. 46, No. 2, pp.109-134, ISSN 0012-1533, Disponível em: go to ISI://WOS:000256105000001.

Yi, M.Y., Fiedler, K.D. and Park, J.S. (2006) 'Understanding the role of individual innovativeness in the acceptance of IT-based innovations: comparative analyses of models and measures', Decision Sciences, August, Vol. 37, No. 3, pp.393-426, ISSN 0011-7315, Disponível em: go to ISI://WOS:000240996900004.

Zemplinerova, A. (2010) 'Innovation activity of firms and competition', Politicka Ekonomie, Vol. 58, No. 6, pp.747-760, ISSN 0032-3233, Disponível em: go to ISI://WOS:00028 7053800002 .

Zeng, S., Xie, X. and Tam, C. (2010) 'Evaluating innovation capabilities for science parks: a system model', Technological and Economic Development of Economy, Vol. 16, No. 3, pp.397-413, ISSN 1392-8619, Disponível em: go to ISI://WOS:000281823900003. 